\title{
The Infection Rates of Trypanosomes in Squirrel Monkeys at Two Sites in the Brazilian Amazon
}

\author{
Mariangela Ziccardi ${ }^{+}$, Ricardo Lourenço-de-Oliveira \\ Laboratório de Transmissores de Hematozoários, Instituto Oswaldo Cruz, Av. Brasil 4365, 21045-900 \\ Rio de Janeiro, RJ, Brasil
}

\begin{abstract}
A study was conducted to determine the prevalence of natural infections by trypanosome species in squirrel monkeys: Saimiri sciureus (Linnaeus) and Saimiri ustus (Geoffroy) caught respectively near 2 hydroelectric plants: Balbina, in the State of Amazonas, and Samuel, in the State of Rondonia, Brazil. A total of 165 squirrel monkeys were examined by thick and thin blood smears (BS), haemocultures and xenodiagnosis: 112 monkeys, $67.9 \%$,(being $52.7 \%$ with mix infections) were positive to trypanosomes. Four species of trypanosomes were found in monkeys from the 2 areas: Trypanosoma (Tejeraia) rangeli Tejera or T. rangeli-like parasites in 58 squirrel monkeys (35.2\%), Trypanosoma (Megatrypanum) minasense Chagas in 55 (33.3\%), Trypanosoma (Herpetosoma) saimirii Rodhain or T. saimirii-like parasites in 53 (32.1\%) and Trypanosoma (Schizotrypanum) cruzi Chagas in 17 (10.3\%). As T. saimirii resembles $\mathrm{T}$. minasense in blood-stream trypomastigotes and $\mathrm{T}$. rangeli in cultural forms and in this survey almost all monkeys presenting trypanosomes morphologically indistinguishable from $\mathrm{T}$. saimirii and/or T. minasense in BS were found through xenodiagnosis and/or haemoculture to be infected by $\mathrm{T}$. rangeli, we suggest that the validity of $\mathrm{T}$. saimirii needs to be evaluated.
\end{abstract}

Key words: Trypanosoma minasense - Trypanosoma saimirii - Trypanosoma rangeli - Trypanosoma cruzi neotropical primates - trypanosomes - trypanosomatid flagellates - Brazil

In certain tropical areas numerous species of monkeys are infected with trypanosomes, some of which are potentially infective to man, such as Trypanosoma cruzi, the agent of Chagas's disease and Trypanosoma rangeli, considered non-pathogenic (Chagas 1924, Deane 1962, Albuquerque \& Barretto 1969, 1970, Deane et al. 1970, Funayama \& Barretto 1970, Hoare 1972, D’ Alessandro 1976, Marinkelle 1976, Rocha \& Barretto 1977, Miles 1979).

At least 7 other trypanosome species, whose infectivity for man is unknown, have been reported in neotropical monkeys and marmosets: T. (Schizotrypanum) prowazecki Berenberg-Gossler, $T$. (Megatrypanum) minasense Chagas, $T$. (Herpetosoma) mycetae Brumpt, T. (Megatrypanum) devei Leger \& Porry, T. (Herpetosoma) saimirii Rodhain, T. (Herpetosoma) diasi Deane $\&$ Martins and T. (Megatrypanum) lambrechti Marinkelle (Deane 1961, 1964, Deane \& Damasceno 1961, Dunn et al. 1963, Marinkelle 1966, 1976, Deane et al. 1970, 1974, 1989, Hoare 1972, Lourenço-de-Oliveira 1988, Lourenço-de-

${ }^{+}$Corresponding author. Fax: +55-21-290.9339

Received 21 August 1996

Accepted 14 March 1997
Oliveira et al. 1991, Resende et al. 1994, Ziccardi et al. 1994).

Squirrel monkeys of the genus Saimiri have been widely used in biomedical research. Saimiri, as well as Aotus monkeys, are successful experimental models (WHO 1988) for human malaria parasites $P$. falciparum and $P$. vivax (Deane et al. 1966, Deane 1967, Geiman \& Meagher 1967, Young \& Rossan 1969, Young et al. 1971, 1975, Rossan et al. 1972 a, b, Schmidt 1978, Gysin et al. 1980, Campbell et al. 1980, Gysin \& Nussenzweig 1982, Gysin \& Fandeur 1983, Collins et al. 1983, Gysin 1991). Squirrel monkeys have also been used in aerospace (Beischer 1968) and pharmacological (Hanson 1968) research. S. sciureus is the most widely used New World monkey in cardiovascular research (Strickland \& Clarkson 1985).

Squirrel monkeys are unusual among laboratory animals; many are captured in forests and not bred for research. Wild-trapped Saimiri monkeys are often naturally infected with pathogens. Sullivan et al. (1993) pointed out that such naturally acquired infections in experimental animals are potential sources of accidental transmission to handlers and uninfected monkeys and may introduce confounding variables into otherwise wellplanned and well-carried out studies. This paper describes the high incidence and diversity of natural infections by trypanosomes in squirrel monkeys from the Brazilian Amazon basin. 


\section{MATERIALS AND METHODS}

The squirrel monkeys were captured in 2 areas, near hydroelectric plants built on rivers on each side of the Amazon basin: Balbina, on the Uatumã River, State of Amazonas ( $\left.1^{\circ} 55^{\prime} \mathrm{S} 59^{\circ} 28^{\prime} \mathrm{W}\right)$ and Samuel, on the Jamari River, State of Rondônia $\left(8^{\circ} 10^{\prime} \mathrm{S} 62^{\circ} 29^{\prime} \mathrm{W}\right)$, Brazil. After the construction of both dams, primates were captured in the forests of the dam reservoir flooded plains. A description of these 2 sites was given by Lourenço-deOliveira and Deane (1995).

From June 1988 to February 1990 blood samples were obtained by venipuncture from 165 squirrel monkeys belonging to 2 species: $70 \mathrm{~S}$. sciureus captured in Balbina and 95 S. ustus from Samuel. The nomenclature and systematics of the primates are according to Hershkovitz (1984). Giemsa-stained thick and thin blood smears (BS) were examined for the presence of trypanosomes. Haemocultures were made from the blood of $24 S$. sciureus and $14 \mathrm{~S}$. ustus in liver infusion tryptose (LIT) over Novy, McNeal and Nicolle medium (NNN) slopes supplemented with $10 \%$ bovine serum and penicillin $200 \mathrm{UI} / \mathrm{ml}$, maintained at $27^{\circ} \mathrm{C}$ for 7 days. The cultures were then microscopically examined weekly for 1 month. The isolated parasites were either subcultured into the same cultural media or cryopreserved in liquid nitrogen.

Twenty two $S$. sciureus and 14 S. ustus, were submitted to xenodiagnosis using 6 nymphs of 3rd and 4th instar of Rhodnius prolixus which were allowed to feed to repletion on each monkey. Fresh smears of faeces and hemolymph of bugs were examined around 30 days after their blood meals. Bugs harboring parasites in their hemolymph were fed on uninfected mice. After 15 days of fasting these bugs fed up on other 20 days-old albino mice. This procedure tended the triatomid's lifespan and allowed the development of the parasites for a longer period of time in the insect, increasing the probability of detecting salivary gland infections and transmission to mice. Fresh blood samples of the mice were examined from 1 to 15 days, when haemoculture (NNN + LIT) was performed.

The salivary glands and gut contents of bugs whose faeces and hemolymph were negative were examined 30 days after xenodiagnosis. Trypanosomes detected in faeces, salivary glands and gut contents of bugs were Giemsa-stained as well as inoculated intraperitoneally (IP) or subcutaneously (SC) into albino mice, whose blood was examined weekly (fresh and Giemsa-stained smears) 30 or 45 days after inoculation. Then, all mice were sacrificed and their blood haemocultured ( NNN + LIT).

Samples of $0.6 \mu \mathrm{l}$ of the haemoculture from 10 squirrel monkeys were injected in the hemocoel of adult $R$. prolixus, which were fed up on 20 daysold albino mice after 30 days and subsequently examined for the search of flagellates in their salivary glands. Blood samples (fresh and Giemsastained smears) of the mice were examined from 1 to 15 days, when haemoculture (NNN + LIT) was performed.

The identification of trypanosome species was done by both morphological analyses and biological parameters (Hoare 1972, D'Alessandro 1976, Miles et al. 1983, Steindel et al. 1991) that included comparisons with standard strains of T. cruzi and T. rangeli (stock R1625 - CDC) for development in arthropod vectors, in culture media and in experimental vertebrate hosts.

\section{RESULTS}

One hundred twelve $(67.9 \%)$ of the squirrel monkeys were infected with trypanosomes; those from Samuel (S. ustus) were more frequently infected $(78.9 \%)$ than those from Balbina $(S$. sciureus) (52.9\%) (Table).

The same 4 Trypanosoma species were detected in squirrel monkeys from both areas: T. minasense, T. rangeli, $T$. cruzi and $T$. saimirii-like. In 8 animals the identification of deformed blood stream trypomastigotes was not possible.

The most common trypanosome species infecting $S$. sciureus was T. saimirii-like, found in $34.3 \%$ (24/70) of individuals, followed by T. rangeli (11/ $70)$ and $T$. rangeli-like parasites $(9 / 70)$ which together accounted for $28.6 \%$ of the total examined. T. minasense was found in $18.6 \%$ and T. cruzi was detected in only 2 .

T. minasense was the most frequent parasite found in S. ustus (44.2\%). T. rangeli were detected in 35 animals $(36.8 \%)$ and $T$. rangeli-like parasites in $3(3.2 \%)$, based on BS, haemoculture and xenodiagnosis. T. saimirii-like parasites were found in $30.5 \%$ of S. ustus and T. cruzi in $15.8 \%$ (Table).

Trypanosomes were isolated in haemoculture from 19 S. sciureus and all 14 S. ustus, which led to the detection and identification of $T$. rangeli and $T$. cruzi. T. rangeli or $T$. rangeli-like parasites was isolated from haemoculture from $14 \mathrm{~S}$. ustus; $T$. cruzi was simultaneously isolated from 3 of them (Table).

T. rangeli was isolated in haemoculture from 8 S. sciureus, 1 of which had a mixed infection with $T$. cruzi. These $T$. rangeli stocks were identical in all pertinent morphological and biological parameters with standard strains. In the haemoculture of 7 other S. sciureus, flagellates morphologically indistinguishable from $T$. rangeli were also found, but these could not be compared biologically to standard stocks. 


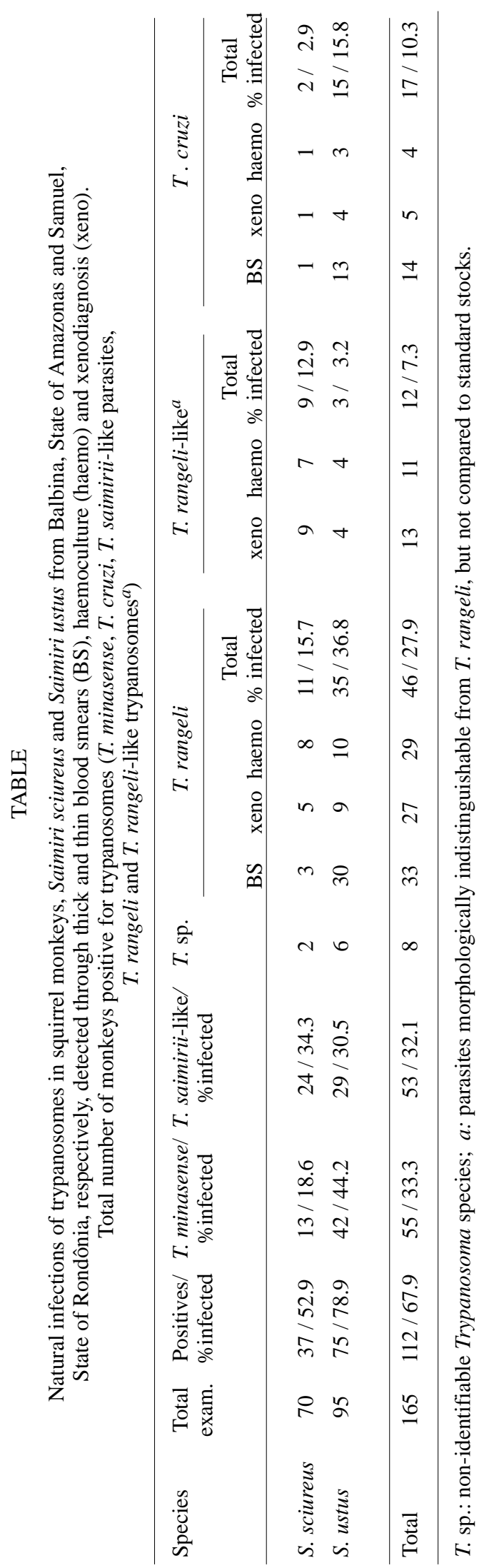

The long and slender epimastigotes among other cultural forms, found in the haemoculture and in the gut of bugs used in xenodiagnosis from $T$. saimirii-like infected squirrel monkeys (as determined by BS) were found to resemble to those of T. rangeli, described by several workers (e.g. Herbig-Sandreuter 1957, Hoare 1972), but distinct from those of T. minasense (Ziccardi et al. 1996). Actually, the cultural forms of T. saimirii described by Rodhain (1937) and Deane and Damasceno (1961) also resemble those of $T$. rangeli.

Following the development in the bug of flagellates isolated from $T$. saimirii-like infected monkeys, we verified that hemolymph and salivary glands became infected in xenodiagnosis of squirrel monkeys numbered 105, 133, 137, 138, 139, $140,147,167$ and 221. In some of these infections, the glands became packed with metatrypanosomes and the parasite was transmitted to mice through biting in half of the cases. Besides, after the injection of $0.6 \mu \mathrm{l}$ of haemoculture from squirrel monkeys numbered 113, 119, 120, 141 and 217 in the hemocoel of adult of $R$. prolixus, the flagellates invaded their salivary glands and $T$. rangeli was transmitted to mice through their biting (except number 141).

Although the identification of parasites as $T$. rangeli by xenodiagnosis or haemoculture in squirrel monkeys numbered 108, 109, 111, 123, 125, 134 and 220 was not possible by biological criteria (such as, development up to metatrypanosomes in the salivary glands of bugs and the transmission to mice through biting) the flagellates developing in both the bugs and haemoculture were morphologically indistinguishable from T. rangeli.

The flagellates from faeces and/or gut contents of triatomines infected with all $T$. rangeli isolates were not infective to mice.

\section{DISCUSSION}

In the Americas, many animals have been examined as reservoirs of microorganisms pathogenic to man. During these surveys, many species of parasites, including trypanosomes, have been found. Except for T. cruzi and T. rangeli, no other trypanosome species is considered potentially pathogenic or infective to humans. However, other trypanosomes may be as frequent as T. cruzi and $T$. rangeli in certain mammals, such as squirrel monkeys (Table).

Approximately $32 \%$ of the squirrel monkey from both study areas were infected with $T$. saimirii-like trypanosomes. This prevalence is much higher than that found by Deane and Damasceno (1961) in S. sciureus from the State of Pará, Brazil (1.38\%). Lourenço-de-Oliveira (1988) and Lourenço-de-Oliveira et al. (1991) reported 
respectively $66.7 \%$ and $28.8 \%$ of a few $S$. sciureus previously examined from Balbina infected with T. saimirii-like parasites, i.e., harboring blood trypomastigotes indistinguishable from those described by Rodhain (1937) and Deane and Damasceno (1961). Lourenço-de-Oliveira et al. (1991) observed that the flagellates developing in haemocultures and triatomine bugs fed on infected squirrel monkeys were indistinguishable from $T$. rangeli, and that in some of the insects the hemolymph and salivary glands became infected.

T. minasense has been recorded from $12 \%$ to $23.1 \%$ of squirrel monkeys from the Amazon, Brazil (Deane et al. 1989, Lourenço-de-Oliveira et al. 1991). Dunn (1968), in a survey of hemoparasites of Saimiri from Colombia and Peru, determined that the prevalence of $T$. minasense and similar trypanosomes was respectively $36.8 \%$ and $47.6 \%$. However, this author considered T. minasense a synonym for a group of simian trypanosomes, some of which are usually considered as distinct species, such as T. devei and T. mycetae (Deane \& Damasceno 1961, Hoare 1972, Lourenço-deOliveira 1988, Deane et al. 1989, Lourenço-deOliveira et al. 1991).

T. rangeli and $T$. rangeli-like parasite was the most frequent trypanosome among the squirrel monkeys from Balbina and Samuel (Table). However, if the haemoculture and xenodiagnosis were performed on all animals a higher incidence of infection by $T$. rangeli would certainly be found.

T. rangeli, or $T$. rangeli-like parasites, are the most frequently reported trypanosome in squirrel monkeys from Colombia, Peru, Panama, Bolivia and Brazil (Dunn et al. 1963, Ayala 1964, Marinkelle 1966, Baker 1972, D'Alessandro et al. 1986, Sullivan et al. 1993). Most authors usually identify the majority of the blood trypomastigotes detected in squirrel monkeys as $T$. rangeli and $T$. rangeli-like, or $T$. minasense, but almost never as $T$. saimirii, due to the fact that $T$. saimirii is poorly characterized. T. saimirii, as described by Rodhain (1941) and other authors (e.g. Deane \& Damasceno 1961), resembles T. minasense in blood-stream trypomastigotes (although narrower, shorter, with its kinetoplast nearer to the posterior end of body that is gradually sharpened to a point, unlike $T$. minasense). Besides, T. saimirii develops in the gut of triatomine bugs, without invading the hemocoel and salivary glands, as $T$. rangeli generally does. On the other hand, T. minasense do not develop in triatomine bugs and its vector is still unknown (Rodhain 1941, Dias \& Campos-Seabra 1943, Deane \& Damasceno 1961).

In this survey almost all squirrel monkeys presenting trypanosomes morphologically indistin- guishable from $T$. saimirii and/or T. minasense in BS were finally found through xenodiagnosis and/ or haemoculture to be infected by $T$. rangeli ( or $T$. rangeli-like). Only 2 animals (numbered 112 and 220) had negative haemoculture and/or xenodiagnosis.

The data presented here strengthen the hypothesis of Deane and Damasceno (1961) that the flagellates developing in the gut of bugs fed on squirrel monkeys infected with $T$. saimirii may belong to another Trypanosoma species undetected by BS. The probability of the squirrel monkeys examined by Rodhain $(1937,1941)$ and Deane and Damasceno (1961) being infected with mixed T. rangeli in subpatent parasitaemia must be considered and the validity of $T$. saimirii needs to be evaluated.

Other monkeys, marmosets and tamarins species from both Balbina and Samuel have also been examined for the search of trypanosomes and plasmodia (Lourenço-de-Oliveira 1988, Deane et al. 1989, Lourenço-de-Oliveira et al. 1991, Deane 1992, Lourenço-de-Oliveira \& Deane 1995).

\section{ACKNOWLEDGEMENTS}

To LP Lounibos for suggestions in the manuscript and "Centrais Elétricas do Norte do Brasil SA (ELETRONORTE)" for support in the field.

\section{REFERENCES}

Albuquerque RDR, Barretto MP 1969. Estudos sôbre reservatórios e vectores silvestres do Trypanosoma cruzi. XXXII - Infecção natural do símio, Callicebus nigrifrons (Spix, 1823) pelo T. cruzi. Rev Inst Med Trop S Paulo 11: 115-122.

Albuquerque RDR, Barretto MP 1970. Estudos sôbre reservatórios e vectores silvestres do Trypanosoma cruzi. XL - Infecção natural do símio Callithrix argentata melanura (Geoffroy, 1812) pelo T. cruzi. Rev Inst Med Trop S Paulo 12: 121-128.

Ayala FM 1964. Presencia de un hemoflagelado semejante al Trypanosoma rangeli Tejera, 1920 en el mono Saimiri boliviensis, en la region amazonica, Peru. Rev Inst Med Trop S Paulo 6: 47-50.

Baker JR 1972. Protozoa of tissues and blood (Other than the Haemosporina), p. 29-56. In RNTW Fiennes, Pathology of Simian Primates. Karger, Basel.

Beischer DE 1968. The squirrel monkey in aerospace medical research, p. 347-364. In LA Rosenblum, RW Cooper (eds), The squirrel monkey. Academic Press, New York and London.

Campbell C, Spencer HC, Chin W, Collins WE 1980. Adaptation of cultured Plasmodium falciparum to the intact squirrel monkey (Saimiri sciureus). Trans $R$ Soc Trop Med Hyg 74: 548-549.

Chagas C 1924. Sôbre a verificação do Trypanosoma cruzi em macacos do Pará (Chrysothrix sciureus). Sciencia Médica 2: 75-76.

Collins WE, Campbell CC, Skinner JC, Chin W, Dinh- 
Nguyen P, Huong AY 1983. Studies on the Indochina I/CDC strain of Plasmodium falciparum in Colombien and Bolivian Aotus monkeys and different anophelines. J Parasit 69: 186-190.

D’Alessandro A 1976. Biology of Trypanosoma (Herpetosoma) rangeli Tejera, 1920, p. 327-403. In WHR Lumsden, DA Evans (eds), Biology of kinetoplastida. Academic Press, London.

D'Alessandro A, Eberhard M, Hincapie O, Halstead S 1986. Trypanosoma cruzi and Trypanosoma rangeli in Saimiri sciureus from Bolivia and Saguinus mistax from Brazil. Am J Trop Med Hyg 35: 285-289.

Deane LM 1961. Tripanosomídeos de mamíferos da Região Amazônica. I. Alguns flagelados encontrados no sangue de mamíferos silvestres do Estado do Pará. Rev Inst Med Trop S Paulo 3: 15-28.

Deane LM 1962. Infecção natural do saguí, Callithrix jacchus, por tripanosoma do tipo cruzi. Rev Inst Med Trop S Paulo 4: 225-229.

Deane LM 1964. Tripanosomídeos de mamíferos da Região Amazônica. III. Hemoscopia e xenodiagnóstico de animais silvestres dos arredores de Belém, Pará. Rev Inst Med Trop S Paulo 6: 225-232.

Deane LM 1967. Monkey malaria in Brazil. A summary of studies performed in 1964-1966. Rev Brasil Biol 27: $213-228$.

Deane LM 1992. Simian malaria in Brazil. Mem Inst Oswaldo Cruz 87 (Suppl. III): 1-20.

Deane LM, Damasceno RG 1961. Tripanosomídeos de mamíferos da Região Amazônica. II. Tripanosomas de macacos da Zona do Salgado, Estado do Pará. Rev Inst Med Trop S Paulo 3: 61-70.

Deane LM, Ferreira Neto J, Silveira IPS 1966. Experimental infection of a splenectomized squirrel monkey, Saimiri sciureus, with Plasmodium vivax. Trans $R$ Soc Trop Med Hyg 60: 811-812.

Deane LM, Silva JE, Loures LF 1974. Nycthemeral variation in the parasitaemia of Trypanosoma minasense in naturally infected marmosets of the genus Callithrix (Primates, Callithricidae). Rev Inst Med Trop S Paulo 16: 1-6.

Deane LM, Batista D, Ferreira Neto JA, Souza H 1970. Tripanosomídeos de mamíferos da Região Amazônica. V. Trypanosoma lambrechti Marinkelle, 1968, em macacos do Estado do Amazonas, Brasil. Rev Inst Med Trop S Paulo 12: 1-7.

Deane LM, Lourenço-de-Oliveira R, Ziccardi MCB, Luz SLB 1989. Simian plasmodia and trypanosomes in Rondônia State, Brazil. Mem Inst Oswaldo Cruz 84 (Suppl. II): 143.

Dias E, Campos-Seabra CA 1943.Trypanosoma conorrhini, hemoparasito do rato transmitido pelo Triatoma rubrofasciata. Presença do vector infectado na cidade do Rio de Janeiro. Mem Inst Oswaldo Cruz 39: 301-330.

Dunn FL 1968. The parasite of Saimiri: in the context of platyrrhine parasitism, p. 31-68. In LA Rosenblum, RW Cooper (eds), The squirrel monkey. Academic Press, New York and London.

Dunn FL, Lambrecht FL, Du Plessis R 1963. Trypanosomes of South American monkeys and marmosets. Am J Trop Med Hyg 12: 524-534.
Funayama GK, Barretto MP 1970. Estudos sôbre reservatórios e vectores silvestres do Trypanosoma cruzi. XLII - Infecção natural do símio, Allouatta caraya (Humboldt, 1812) pelo T. cruzi. Rev Inst Med Trop S Paulo 12: 257-265.

Geiman QM, Meagher MJ 1967. Susceptibility of a New World monkey to Plasmodium falciparum from man. Nature 215: 437-439.

Gysin J 1991. Relevance of the squirrel monkey as a model for experimental human malaria. Res Immunol 142: 649-654.

Gysin J, Fandeur T 1983. Saimiri sciureus (Karyotype 14-7): an alternative experimental model of Plasmodium falciparum infection. Am J Trop Med Hyg 32: 461-467.

Gysin J, Nussenzweig RS 1982. The use of squirrel monkey (Saimiri sciureus) in investigate the immune response to sporozoites of a human malaria parasite Plasmodium vivax. Mol Biochem Parasitol (Suppl.): 95.

Gysin J, Hommel M, Pereira da Silva L 1980. Experimental infection of the squirrel monkey (Saimiri sciureus) with Plasmodium falciparum. J Parasitol 66: 1003-1009.

Hanson HM 1968. Use of the squirrel monkey in pharmacology, p. 365-392. In LA Rosenblum, RW Cooper (eds), The squirrel monkey. Academic Press, New York and London.

Herbig-Sandreuter A 1957. Further studies on Trypanosoma rangeli Tejera, 1920. Acta Tropica 4: 193-207.

Hershkovitz P 1984. Taxonomy of squirrel monkeys genus Saimiri (Cebidae, Platyrrhini): A preliminary report with description of a hitherto unnamed form. Am J Primatol 7: 155-210.

Hoare CA 1972. The trypanosomes of mammals. Blackwell Scientific Publication, Oxford, 749 pp.

Lourenço-de-Oliveira R 1988. Hemoparasitos encontrados em alguns mamíferos de Balbina, Estado do Amazonas. Mem Inst Oswaldo Cruz 83 (Suppl. I): 233.

Lourenço-de-Oliveira R, Deane LM 1995. Simian malaria at two sites in the Brazilian Amazon. I - The infection rates of Plasmodium brasilianum in nonhuman primates. Mem Inst Oswaldo Cruz 90: 331339.

Lourenço-de-Oliveira R, Ziccardi M, Bessa-Luz SL 1991. Additional notes on the trypanosomes in nonhuman primates from Balbina, Amazonas state, Brazil. Mem Inst Oswaldo Cruz 86 (Suppl. I): 140.

Marinkelle CJ 1966. Observations on human, monkey and bat trypanosomes and their vectors in Colombia. Trans R Soc Trop Med Hyg 60: 109-116.

Marinkelle CJ 1976. The biology of the trypanosomes of non-human primates, p. 217-256. In WHR Lumsden, DA Evans (eds), Biology of kinetoplastida. Academic Press, New York.

Miles MA 1979. Transmission cycles and the heterogeneity of Trypanosoma cruzi, p. 117-196. In WHR Lumsden, DA Evans (eds), Biology of kinetoplastida. Academic Press, London.

Miles MA, Arias JR, Valente SAS, Naiff RD, De Souza AA, Povoa MM, Lima JAN, Cedillos RA 1983. 
Vertebrate hosts and vectors of Trypanosoma rangeli in the Amazon basin of Brazil. Am J Trop Med Hyg 32: 1251-1259.

Resende DM, Pereira LH, Lôbo A 1994. Long-term patency of blood parasitism by Trypanosoma minasense and Microfilariae in Callithrix penicillata marmosets (Primates, Callitrichidae), caught in wild and maintained in captivity. Mem Inst Oswaldo Cruz 89: 127-128.

Rocha GM, Barretto MP 1977. Estudos sobre reservatórios e vectores silvestres do Trypanosoma cruzi. LXV: infecção natural do símio Callithrix geoffroyi (Humboldt, 1812) pelo T. cruzi. Rev Brasil Biol 37: 419-424.

Rodhain J 1937. Notes sur Trypanosoma minasense Chagas. C R Soc Biol 125: 1034-1036.

Rodhain J 1941. Notes sur Trypanosoma minasense Chagas. Identité spécifique du Trypanosome du Saimiri: Chrysothrix sciureus. Acta Biol Belg 1: 187 192.

Rossan RN, Baerg DC, Young MD 1972a. Characteristics of Plasmodium vivax infections in Saimiri sciureus (squirrel monkey). Proc Helm Soc Wash 39: 24-28.

Rossan RN, Young MD, Baerg DC 1972b. Trophozoite induced infections of Plasmodium falciparum in Saimiri sciureus (squirrel monkey). Proc Helm Soc Wash 39: 21-24.

Schmidt LH 1978. Plasmodium falciparum and Plasmodium vivax infections in the owl monkey (Aotus trivirgatus) I. The courses of untreated infections. Am J Trop Med Hyg 27: 671-702.

Steindel M, Carvalho Pinto JC, Toma HK, Mangia RHR, Ribeiro-Rodrigues R, Romanha AJ 1991. Trypanosoma rangeli (Tejera, 1920) isolated from a sylvatic rodent (Echimys dasythrix) in Santa Catarina island, Santa Catarina state: first report of this trypanosome in Southern Brazil. Mem Inst Oswaldo Cruz 86: 7379.

Strickland HL, Clarkson TB 1985. Use of squirrel monkeys in cardiovascular research, p. 295-313. In LA Rosenblum, CL Coe (eds), Handbook of squirrel monkey research. Plenum Press, New York and London.

Sullivan JJ, Steurer F, Benavides G, Tarleton RL, Eberhard ML, Landry S 1993. Trypanosomes and microfilariae in feral owl and squirrel monkeys maintained in research colonies. Am J Trop Med Hyg 49 . 254-259.

WHO 1988. Role of non-human primates in malaria vaccines development. Bull Org mond Santé 66: 719728.

Young MD, Rossan RN 1969. Plasmodium falciparum induced in the squirrel monkey, Saimiri sciureus. Trans $R$ Soc Trop Med Hyg 63: 686-687.

Young MD, Baerg DC, Rossan RN 1971. Sporozoite transmission and serial blood passage of Plasmodium vivax in squirrel monkey (Saimiri sciureus). Trans $R$ Soc Trop Med Hyg 65: 835-836.

Young MD, Baerg DC, Rossan RN 1975. Experimental monkey hosts for human plasmodia. Exp Parasitol 38: 136-152.

Ziccardi M, Lourenço-de-Oliveira R, Nogueira R 1996. The haemoculture of Trypanosoma minasense Chagas, 1908. Mem Inst Oswaldo Cruz 91: 501-505.

Ziccardi M, Moreira GV, Pissinatti A, Lourenço-deOliveira R 1994. Trypanosoma cruzi and Trypanosoma minasense in lion tamarins (Primates: Callithrichidae). Mem Inst Oswaldo Cruz 89 (Suppl. I): 55 . 